\title{
The Presidential Election of 1932 in Iowa
}

Philip A. Grant

On July 2, 1932 Governor Franklin D. Roosevelt of New York was nominated by the Democratic Party as its candidate for president of the United States. ${ }^{1}$ Sixteen days earlier the Republicans had renominated incumbent President Herbert Hoover. ${ }^{2}$ Although the two major political parties had officially chosen their respective presidential candidates by early July, the campaign of 1932 did not actually begin until Labor Day weekend.

Between September 5 and November 7 the American electorate had the opportunity to evaluate the Democratic and Republican candidates. During these ten eventful weeks both Governor Roosevelt and President Hoover traveled throughout the nation, delivered formal addresses over the various radio networks, and issued a multitude of detailed position papers on their campaign promises. ${ }^{3}$

Among the foremost of the nation's farm states involved in

'Official Report of the Proceedings of the Democratic National Convention, 1932 (Chicago: 1932), 206-331; William E. Leuchtenberg, Franklin D. Roosevelt and the New Deal, 1932-1940 (New York: Harper and Row Publishers, 1963), 7-10.

${ }^{2}$ Official Report of the Proceedings of the Republican National Convention, 1932 (New York: 1932), 167-200; Richard C. Bain and Judith H. Parris, Convention Decisions and Voting Records (Washington: The Brookings Institution, 1973), 234-238.

${ }^{3}$ The following works provide scholarly accounts of the presidential election of 1932: Frank Freidel, Franklin D. Roosevelt: The Triumph (Boston: Little Brown and Company, 1936), 323371; Edgar E. Robinson and Vaughn R. Bornet, Herbert Hoover, President of the United States (Stanford: Stanford University Press, 1975), 239-254; Arthur M. Schlesinger, Jr., The Crisis of the Old Order, 1919-1933 (Boston: Houghton Mifflin Company, 1957), 413-439; Jordan A. Schwarz, The Interregnum of Despair (Urbana: University of Illinois Press, 1970), 195-204. 
the presidential election of 1932 was Iowa. Having a population of slightly less than two and one-half million, Iowa in 1932 was allotted a total of eleven electoral votes. ${ }^{4}$ Iowa had cast its electoral votes for the victorious candidate in eight of the nine presidential elections since $1896 .{ }^{5}$

Between the beginning of the twentieth century and the election of 1930 Iowa had been a steadfastly Republican state. Not only had Iowa maintained a tradition of sending Republicans to the United States Senate and House of Representatives, ${ }^{6}$ but it also had voted for Republicans in fifteen successive gubernatorial elections since 1901. ${ }^{7}$

The Republican Party had emerged triumphant in Iowa's three presidential elections in the decade after World War I. In November 1920 Senator Warren G. Harding had carried Iowa by 406,869 votes $(73.6 \%),{ }^{8}$ while four years later President Calvin Coolidge had recorded a somewhat more modest plurality of $263,010(55.3 \%) .{ }^{9}$ Finally, in 1928 Secretary of Commerce Herbert Hoover, a native Iowan, had defeated his Democratic opponent, Governor Alfred E. Smith, by a 623,570-379,011 margin $(62.2 \%) .{ }^{10}$ Primarily because of the divisive issues of religion and prohibition, Hoover in 1928 succeeded in carrying ninety-three of Iowa's ninety-nine counties. ${ }^{11}$

By the late summer of 1932 many Iowa Democrats were optimistic about their party's prospects in the November

'Between 1920 and 1930 Iowa's population had increased from $2,404,021$ to $2,470,939$. Located near the geographic center of the United States, it was the most populous state between Illinois and California. Department of Commerce, Abstract of the Fifteenth Census of the United States, 1930 (Washington: United States Government Printing Office, 1933), 10-11.

${ }^{5}$ Svend Peterson, A Statistical History of the American Presidential Elections (New York: Frederick Ungar Publishing Company, 1963), 64, 67, 70, 74, 78, 81, 83, 86, 89.

'Between 1900 and 1930 the Republicans had won fourteen of fifteen contests for the United States Senate and had prevailed in all but eight of the one hundred and seventy-six campaigns for seats in the House of Representatives. Guide to U.S. Elections (Washington: Congressional Quarterly, Inc., 1975), 463, 491, 687-688, 692-693, 698, 703, 708, 712-713, 718, 725, 731, 736-737, 742, 747, 752, 762, 766-767.

'Guide to U.S. Elections, 407.

-The 1920 results had been as follows: Warren G. Harding (Republican) 634,674; James M. Cox (Democrat) 227,924. State of Iowa, Official Register, 1921-1922 (Des Moines: 1921), 452-454.

'The statistics in 1924 were as follows: Calvin Coolidge (Republican) 537,458; Robert M. LaFollette (Progressive) 274,448; John W. Davis (Democrat) 160,382. Official Register, 19251926, 536-537.

${ }^{10}$ Official Register, 1929-1930, 422-423.

"Smith, an urban Catholic and an avowed critic of the Eighteenth (Prohibition) Amendment, carried only Audubon, Carroll, Crawford, Dubuque, Plymouth, and Shelby Counties. 
election. First, they knew that nearly three years had elapsed since the outbreak of the 1929 financial crisis and suspected that a substantial number of their fellow citizens were losing confidence in the ability of President Hoover to solve the vexing problems brought about by the Great Depression. ${ }^{12}$ Second, they realized that the Republicans had engaged in a number of especially acrimonious primary contests in $1932 .{ }^{13}$ Third, the Democrats were consoled by the facts that two years earlier they had unseated a Republican congressman and had greatly increased their percentage of the state's overall congressional vote. ${ }^{14}$ These factors prompted some Democrats to anticipate that Iowa, notwithstanding its Republican heritage, might favor their party in November 1932.

Two well-known political figures, former Senator James A. Reed of Missouri and Senator George W. Norris of Nebraska, campaigned for Roosevelt in Iowa. Having been a member of the Senate between 1911 and 1929, Reed was widely acknowledged as one of the country's most flamboyant political orators. Norris, who had been serving in Congress as a Republican since 1903, was Chairman of the Senate Committee on the Judiciary and one of the most zealous and articulate leaders of the bipartisan farm block on Capitol Hill.

Deploring the economic misfortunes plaguing the nation, Reed blamed the Republican Party "for the catastrophe which swept away the vast part of the wealth of this county." The Missourian, analyzing portions of the president's campaign speeches, construed certain Hoover utterances as a "series of incorrect statements and unjustifiable deductions." Alleging

\footnotetext{
${ }^{12}$ Detailed analyses of the adverse effects of the Great Depression on Iowa and other farm states may be found in the following works: Broadus Mitchell, Depression Decade, 1929-1941 (New York: Rinehart and Company, Inc., 1947), 64-76; Theoaore Saloutos and John D. Hicks, Agricultural Discontent in the Middle West, 1900-1939 (Madison: University of Wisconsin Press, 1951), 404-446; Harris G. Warren, Herbert Hoover and the Great Depression (New York: Oxford University Press, 1959), 168-187.

${ }^{13}$ The 1932 Republican primary culminated in the defeat of incumbent Senator Smith W. Brookhart of Washington by Henry Field of Shenandoah, a seed dealer and radio station operator. Another prominent Iowa Republican, veteran Representative Gilbert N. Haugen won his primary contest by less than six hundred votes, while two other Republican congressmen, Lloyd Thurston and C. William Ramseyer, had been forced to run against one another in a newly reapportioned district.

${ }^{14}$ In 1930 the Democrats had elected Bernhard C. Jacobsen of Clinton in Iowa's Second Congressional District. Moreover, the Democrats, having received only $29.3 \%$ of the 1928 congressional vote, increased their 1930 proportion to $41.9 \%$. Official Register, 1931-1932, 444 447.
} 
that the predictions ventured by the president had "come to naught," Reed climaxed his remarks: "Surely the time has come when we should cease to place confidence in either the prophecies or the schemes of Mr. Hoover." 15

Norris emphasized the record of the Hoover administration on agriculture. Charging that Hoover had been insensitive to the need for farm relief both as secretary of commerce and president, the Nebraskan insisted that the chief executive had failed to redeem "every pledge he made to the farmers." Norris, speculating on the reaction of the electorate to the president's bid for re-election, asked whether the American people would permit their destinies to remain "in the hands of one who has never yet made a promise or a prophecy which has been fulfilled." 16

In addition to the efforts of the local Republican leaders, Vice-President Charles Curtis and Secretary of War Patrick J. Hurley campaigned for Hoover in Iowa. Curtis had represented Kansas both in the House and Senate for many years before assuming the vice-presidency in March 1929, while Hurley was in the midst of a lengthy and distinguished career in politics and diplomacy.

Curtis, arguing that the origins of the problems afflicting American agriculture could be traced to the administration of Democratic President Woodrow Wilson, stressed that Roosevelt had virtually ignored the issue of farm relief until the advent of his presidential quest. Also voicing unqualified praise of the historic Republican policy for maintaining high tariffs, the vicepresident charged that Roosevelt favored "letting down the tariff bars so foreign goods can come in in large quantities." As to the thrust of Roosevelt's campaign promises, Curtis ridiculed the fact that the New York governor had merely "mentioned the plans and then said he would bring them up for further discussion in congress if he were elected." ${ }_{17}$

Appearing in Keokuk and Davenport, Hurley acclaimed President Hoover's ability to keep the United States on the gold standard as a "momentous achievement." The secretary of war, stating that the American people had been thoroughly informed

${ }^{15}$ Register, Des Moines, Iowa, October 11, 1932, 1, 5.

${ }^{16}$ Ibid., October 23, 1932, 1, 5.

${ }^{17} J o u r n a l$, Sioux City, Iowa, October 22, 1932, 1, 5. 
of the president's positions on all the vital questions of 1932, complained that Roosevelt had failed "to make himself clear on a single issue." Lauding Hoover's "brilliant campaign against depression," Hurley concluded that, because of the president's leadership, the United States stood "firm, solvent and confident of the future." ${ }^{18}$

The highlights of the 1932 campaign in Iowa occurred when Governor Roosevelt and President Hoover delivered major political speeches in two of the state's largest cities. Roosevelt's appearance took place in Sioux City on September 29, while Hoover spoke in Des Moines on October 3.

Roosevelt, severely condemning the economic policies of the Hoover administration, was especially vociferous in his criticisms of the president's records on foreign trade and agriculture. Regretting that the initial effect of the "notorious and indefensible" protective tariff had been to "increase or sustain the cost of all that agriculture buys," the New York governor insisted that the tariff had "ruined our export trade in industrial products as well." Roosevelt, also expressing consternation at the plight of American agriculture, pledged that, if elected, he would strive to assist the farmer as follows:

... first, for us to seek relief for him from the burden of his expense account, and, second, to try to restore the purchasing power of his dollar by getting for him higher prices for the products of the soil.

Reminding his audience of the "tragic consequences of the depression," Roosevelt climaxed his address by deploring the fact that during the Hoover years the labors of the American people had been "lost in the smash of an economic system that was unable to fulfill its purposes." 19

The president, reviewing the performance of the Democrats in Congress, denounced the opposition party members for having brought "discouragement and delay" to the return of economic prosperity. Warning that the Democratic pledge to reduce tariffs would "disturb every possibility of recovery," he emphasized that the "very basis of safety to American agricul-

${ }^{18}$ Gate City, Keokuk, Iowa, October 7, 1932, 1, 6; Democrat, Davenport, Iowa, October 7, $1932,4$.

${ }^{19}$ The Public Papers and Addresses of Franklin D. Roosevelt, 1928-1932 (New York: Random House, 1938), 756-770; Journal, Sioux City, Iowa, September 30, 1932, 1, 7, 8. 
ture is the protective tariff on farm products." Hoover contended that abandonment of the gold standard would have signified "utter chaos" and expressed pride that his administration had "kept a cool head and rejected every counsel of weakness and cowardice." Terminating his remarks by proclaiming that the battle against depression was gathering momentum, the president concluded that "we have turned the tide from defense to attack." 20

Reaction to President Hoover's address was varied. Among the prominent Iowans venturing to comment were Henry A. Wallace of Des Moines, a future secretary of agriculture and vice-president, and Senator Lester J. Dickinson of Algona, who had been the keynote speaker at the 1932 Republican National Convention. Wallace, ridiculing Hoover's appearance as a "beautifully staged affair," charged that the vast majority of tickets had been systematically distributed to Republican office holders and precinct workers. Elated that the president had demolished certain of Roosevelt's ideas, Dickinson applauded Hoover for having thrown a "welcome light on the cold, hard facts of present economic conditions." Two Iowa newspapers, the Davenport Times and Cedar Rapids Gazette-Republican, were generous in their praise of Hoover's address, while two other of the state's daily publications, the Des Moines Register and Dubuque Telegraph-Herald, merely editorialized that the president had expressed himself on issues of vital importance. Three newspapers in neighboring states also analyzed Hoover's Iowa address. The Milwaukee Journal and Saint Louis Post-Dispatch voiced disappointment, while the Chicago Tribune felt that the speech was very effective. ${ }^{21}$

Three of the several public opinion surveys of Iowa political sentiment in 1932 were commissioned by the Des Moines Register, the Hearst newspaper chain, and the Farm Journal. The Register, Iowa's largest circulating daily newspaper, in early

${ }^{20}$ The Memoirs of Herbert Hoover, 1929-1941 (New York: The Macmillan Company, 1952), 267, 279-283, 290-291, 297, 305-307, 308; Register, Des Moines, Iowa, October 4, 1932, 1 ; October 5, 1932, 12, 13.

"'Samplings of reactions to the president's Des Moines address may be found in the following newspapers: Times, New York, N.Y., October 6, 1932, 1, 16, 17; Herald Tribune, New York, N.Y., October 6, 1932, 1, 2, 6; Evening Star, Washington, D.C., October 5, 1932, 1, 4; Journal, Milwaukee, Wis., October 5, 1932, 12; October 6, 1932; 3; Post-Dispatch, Saint Louis, Mo., October 6, 1932, 1-A, 2-A, 2-B; Tribune, Chicago, Ill., October 6, 1932, 10, 12. 
October reported that Roosevelt outpolled Hoover 45,509-27,981 $(62.2 \%)$ in its straw vote among Iowans. ${ }^{22}$ The results of the Hearst poll were compiled by the New York American, and the bulk of the figures were released during the final ten days of the presidential campaign. On October 26 Roosevelt led Hoover 6,654-5,556 (54.5\%), while on November 5 Roosevelt's victory margin was 6,994-5,944 (54.4\%). ${ }^{23}$ The Farm Journal survey was confined primarily to Iowa's agrarian communities. In its October issue this publication gave Roosevelt a 38-30 advantage $(55.9 \%)$ and in the November issue the New York governor defeated the president $114-44(72.9 \%) .^{24}$

Perhaps even more discouraging for the Republicans were three polls sponsored by the highly respected Literary Digest in late October and early November. The Literary Digest canvasses, based on personal contacts with hundreds of thousands of American citizens, were regarded as highly scientific by 1932 standards. In its initial sampling published on October 22, the Literary Digest found that Roosevelt outpolled Hoover 28,68520,117 in Iowa. ${ }^{25}$ In its second tabulation, released one week later, Roosevelt led Hoover 31,825-22,417 in Iowa. ${ }^{26}$ In its final poll on November 5, Roosevelt received 32,956 votes as contrasted with Hoover's 23,372. ${ }^{27}$ Thus, Roosevelt's proportions in the three polls varied only from $57.8 \%$ to $57.9 \%$. Based on the total presidential vote of 1928 , the final Literary Digest poll indicated that Roosevelt would carry Iowa by a minimum of one hundred and fifty thousand votes. Also, in surveys of individual cities it forecast that Roosevelt would run extremely well in six of Iowa's largest communities. ${ }^{28}$

On November 8, 1932 a record number of Iowans went to the polls to choose between Roosevelt and Hoover. ${ }^{29}$ The early returns indicated an unmistakable Roosevelt trend in all parts of

${ }^{22}$ Register, Des Moines, Iowa, October 2, $1932,1$.

${ }^{23}$ American, New York, N.Y., October 26, 1932, 3; November 5, 1932, 5.

${ }^{24}$ Farm Journal, October 1932, 6; November 1932, 6.

${ }^{25}$ Literary Digest, October 22, 1932, 9.

${ }^{26}$ Ibid., October 29, $1932,9$.

${ }^{27}$ Ibid., November 5, 1932, 8.

${ }^{28}$ The figures for these communities were as follows: Des Moines $53.6 \%$; Davenport $59.8 \%$; Council Bluffs $66.8 \%$; Mason City $59.1 \%$; Burlington $71.3 \%$; Clinton $66.6 \%$.

${ }^{29}$ In 1932 the overall presidential vote was $1,036,687$, thus exceeding the 1928 total of $1,009,289$ by more than twenty-seven thousand votes. 
the state. By midnight it was evident that Hoover had experienced a humiliating electoral defeat. The official tabulation, completed several days after the ballots were actually cast, was as follows: Roosevelt 598,019 (59.1\%); Hoover 414,433 $(40.9 \%){ }^{30}$ Roosevelt in outpolling Hoover by more than one hundred and eighty-four thousand votes became only the second Democrat ever to carry Iowa.$^{31}$ Altogether the New York governor succeeded in winning all but six of Iowa's ninety-nine counties. $^{32}$

Even more impressive than Roosevelt's statewide majority was his showing in Iowa's eighty-eight primarily rural counties. The New York governor won eighty-five of these counties, defeating Hoover 415,485-276,721 (60.1\%). The substantial Roosevelt proportion was in sharp contrast to the mere $33.5 \%$ of the rural vote polled by Smith in 1928 .

Although Smith had fared somewhat better in Iowa's eleven most populous counties in 1928, Roosevelt attracted a considerably higher percentage of the ballots in 1932 . The comparative figures for these counties were as follows:

1928

1932

\begin{tabular}{|c|c|c|c|c|}
\hline & Hoover & Smith & Roosevelt & Hoover \\
\hline Polk County & 42,290 & 19,725 & 31,517 & 34,023 \\
\hline Woodbury County & 20,587 & 16,831 & 26,397 & 12,764 \\
\hline Linn County & 25,452 & 11,715 & 17,693 & 18,733 \\
\hline Blackhawk County & 20,942 & 8,467 & 14,660 & 14,746 \\
\hline Scott County & 16,974 & 12,942 & 16,887 & 14,218 \\
\hline Dubuque County & 9,784 & 19,437 & 19,210 & 6,747 \\
\hline Pottawattomie County & 14,354 & 9,905 & 16,674 & 9,085 \\
\hline Clinton County & 12,297 & 8,643 & 12,587 & 9,005 \\
\hline Des Moines County & 10,547 & 5,578 & 9,395 & 5,590 \\
\hline Johnson County & 7,288 & 7,181 & 8,764 & 5,484 \\
\hline \multirow[t]{2}{*}{ Cerro Gordo County } & 9,582 & 4,908 & 8,752 & 7,317 \\
\hline & 190,032 & 125,332 & 182,534 & 137,712 \\
\hline
\end{tabular}

${ }^{30}$ Statistical History of American Presidential Elections, 92.

${ }^{31}$ In 1912 Woodrow Wilson had outpolled former President Theodore Roosevelt and President William Howard Taft. The 1912 vote distribution had been as follows: Wilson (Democrat) 185,325; Roosevelt (Progressive) 161,819; Taft (Republican) 119,805. Statistical History of American Presidential Elections, 78.

${ }^{32}$ The following counties were carried by Hoover in 1932; Blackhawk (14,746-14,680); Linn (18,733-17,693); Marshall (6,604-6,385); Polk (34,023-31,517); Story $(6,735-5,638)$; Warren $(3,725-3,542)$. 
Thus, in these eleven largely urban counties a Smith deficit of 64,700 was transformed into a Roosevelt surplus of 44,822 and a Smith proportion of $39.7 \%$ was increased to a Roosevelt proportion of $56.7 \%$.

There was no doubt that Roosevelt's landslide victory proved extremely helpful to many candidates for state, congressional, and legislative offices in Iowa. In 1932 Democrat Clyde L. Herring of Des Moines defeated incumbent Republican Governor Dan W. Turner of Corning, ${ }^{33}$ while Democract Richard L. Murphy of Dubuque outpolled his Republican opponent, Henry Field of Shenandoah, for a seat in the United States Senate. ${ }^{34}$ Among the hundreds of other Democrats elected in Iowa were six of nine candidates for the House of Representatives ${ }^{35}$ and more than sixty percent of the party's aspirants for the State Legislature. ${ }^{36}$ The 1932 results were somewhat astonishing for a state which had been solidly Republican since the beginning of the twentieth century.

In the election of 1932 Roosevelt was unquestionably the beneficiary of the profound discontent over the precarious state of Iowa's economy. From personal experience most voters realized how acutely Iowa had suffered during the four years of Hoover's presidency. As a state located conspicuously in the geographic center of the United States, Iowa in many respects mirrored the economic problems plaguing other states and regions of the nation. Iowa, of course, ranked as one of the country's principal farm states, and, similar to its sister agricultural states in the Midwest, had undergone the most severe excesses of the Great Depression. ${ }^{37}$

${ }^{33}$ Herring was victorious over Turner by a $508,573-455,145$ majority. Official Register, 1933-1934, 248-249.

${ }^{34}$ The official result of the senatorial race was as follows: Murphy 538,422; Field 399,929. Official Register, 1933-1934, 250-251.

${ }^{35}$ The Democrats elected to the House of Representatives were Edward C. Eicher of Washington, Bernhard M. Jacobsen of Clinton, Albert C. Willford of Waterloo, Fred Biermann of Decorah, Otha D. Wearin of Hastings, and Guy M. Gillette of Cherokee. Lawrence F. Kennedy (comp.), Biographical Directory of the American Congress, 1774-1971 (Washington: United States Government Printing Office, 1971), 370.

${ }^{36}$ When the Iowa Legislature convened in 1933, the Democrats enjoyed majorities of 28-26 in the State Senate and 77-36 in the House of Representatives. Official Register, 1933-1934, 73-77.

${ }^{37}$ The following statistics, contrasting economic developments in different years, revealed how seriously the Iowa economy had declined: Farm Income $\$ 735,700,000(1929)-\$ 311,400,000$ (1932); Wheat \$1.04/bushel (1929)— \$0.38/bushel (1932); Corn \$0.80/bushel (1929)—\$0.32/ 


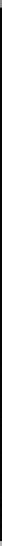

President Franklin D. Roosevelt and Iowa Governor Clyde L. Herringboth Democrats and both beneficiaries of Iowa's liberal vote in the 1932 presidential election.

Iowa, like most of the forty-two states in the Roosevelt column, ${ }^{38}$ was reacting against both the accumulated shortcomings of twelve years of Republican administrations and the apparent failure of Herbert Hoover to cope with the Great Depression. It seems reasonable to assume that a sizeable number of Iowans cast their votes against Hoover rather than for Roosevelt. ${ }^{39}$ The presidential election of 1932 certainly indicated that a commanding majority of the citizens of Iowa distinctly favored a change in national leadership. The presidential election of 1932 marked the beginning of a genuine two party system in Iowa.

bushel (1932); Oats $\$ 0.42 /$ bushel (1929) - $\$ 0.16 /$ bushel (1932); Corporate Income Taxes $\$ 68,046,000$ (1929)- $\$ 11,239,000$ (1932); Individual Income Taxes $\$ 222,103,000$ (1929)$\$ 109,842,000$ (1932); Liabilities of Business Failures $\$ 3,075,000$ (1929)— $\$ 7,081,000$ (1932); Factory Workers 82,615 (1929)—52,137 (1933); Manufacturing Wages $\$ 103,532,000$ (1929)$\$ 68,274,000$ (1933); Value of Industrial Products $\$ 907,929,000$ (1929)- $\$ 381,668,000$ (1933).

${ }^{38}$ In 1932 Hoover also lost the six states surrounding Iowa. Roosevelt's majorities in these states were as follows: Illinois 449,548; Missouri 460,693; Nebraska 157,905; South Dakota 84,303 ; Minnesota 236,847; and Wisconsin 359,669. In scoring an overwhelming victory Roosevelt won the popular vote $22,809,638-15,758,901$ and the electoral vote $472-59$. Statistical History of American Presidential Elections, 92.

${ }^{39}$ In Iowa the difference between Hoover's impressive 1928 plurality and his substantial 1932 deficit amounted to 632,092 votes. 
Copyright of Annals of Iowa is the property of State of Iowa, by \& through the State Historical Society of Iowa and its content may not be copied or emailed to multiple sites or posted to a listserv without the copyright holder's express written permission. However, users may print, download, or email articles for individual use. 